Relations industrielles

Industrial Relations

\title{
Authority in the Business Firm
}

\section{Victor Morency}

Volume 5, numéro 6, mars 1950

URI : https://id.erudit.org/iderudit/1023355ar

DOI : https://doi.org/10.7202/1023355ar

Aller au sommaire du numéro

\section{Éditeur(s)}

Département des relations industrielles de l’Université Laval

\section{ISSN}

0034-379X (imprimé)

1703-8138 (numérique)

Découvrir la revue

Citer cet article

Morency, V. (1950). Authority in the Business Firm. Relations industrielles /

Industrial Relations, 5(6), 56-57. https://doi.org/10.7202/1023355ar

Tous droits réservés @ Département des relations industrielles de l’Université Laval, 1950
Ce document est protégé par la loi sur le droit d'auteur. L’utilisation des services d'Érudit (y compris la reproduction) est assujettie à sa politique d'utilisation que vous pouvez consulter en ligne.

https://apropos.erudit.org/fr/usagers/politique-dutilisation/ 


\section{AUTHORITY IN THE BUSINESS FIRM}

\section{Victor MORENCY}

The legitimacy of the authority wielded in a firm owned by a single proprietor or by a family is based on an argument from psychology and on the natural right each man has to manage his own possessions. Save for rare exceptions, investment of capital in such enterprises constitutes a risk; hence it is a psychological necessity for the investors to be guaranteed the right which they deem necessary, narzely to have the right to designate the authority in the firm, for without this guarantee they would refuse to risk their funds.

This argument has much less force - does it have any at all ? - in the case of the corporation. The shareholders, who are the legal holders of the capital in the society which the corporation forms, have, in theory, the power to appoint the management in the business; but to estimate how much of this power they actually exercise, one needs only to compare the total number of shareholders to the number present at general meetings.

This is why the psychological argument about capital holders refusing to invest unless they can control the management does not apply to the corporation, the choice of its management being left as it is to a small number. For it is this small number of shareholders which, in the end, comes to wield authority continually.

One may ask if this is not the meaning of the statement made by Pius XII on May 7, 1949 before UNIAPAC - " The owner of the means of production, whether a single proprietor, a workers' association or an institution, must, while remaining always within the limits of public economic rights, remain master of his decisions", since he took pains to make clear what he meant by "owner of the means of production".

It is important to distinguish in the concept of authority its raison d'être and the power it implies. Anyone who, by virtue of inheritance or election, directs an enterprise, exercises a power which, as Jean Predseil says, "is often only a more or less accidental material fact". ${ }^{1}$ Moreover, this power, if ill founded and poorly exercised, prevents the enterprise from doing its proper work, which is to attain its common good. It is only by a compelling moral power, a well

(1) PredseIL, Jean, "Participation ouvrière et autorité patronale", Industrie, October 1949, p. 627. tested care for justice combined with the appropriate technical knowledge, that the head of a business can be sure of being accepted by his collaborators, not under coercion, but in freedom and confidence. Let us have no illusions. The minute the worker begins to doubt the morality, the spirit of justice, and the know-how of the employer, his obedience ceases to be free, and therefore ceases to be effective, and becomes instead a forced submission which, the first chance he gets, he will transform into a gesture of resentment or rebellion.

This was underlined by the 1945 assembly of the French cardinals and archbishops: "To accomplish these social advances (the promotion of the working class) structural reforms are necessary. We are ready to welcome them, but in order that they be more effective, it is necessary that the unity of command and the authority of the head of each enterprise, based on competence and ethical right, be fully recognized, that there be no compromising of legitimately acquired rights, that the capacity of the national economy be prudently taken into account, and that all spirit of violence be excluded ".

Since with most of those of us who are business leaders it is Providence which has given us our power, without much effort on our part, let us seek to exercise it in a way which will transform the obedience of our employees into a gesture of spontaneous collaboration.

To speak of sharing the authority of the business leader and to contest his monopoly of the business function is not necessarily to climb onto the Marxist bandwagon. A business firm is a human community where authority is justified only by its service in assuring the common good. Too many employers, however, have exercised their authority only for their own interests and to the detriment of the workmen, and thus to the detriment of the business itself, thus ceasing to fulfill their legitimate function as leader.

What to do, in such a case, in face of the all too just demands of the workers? Help the employers maintain their positions acquired during the course of the last century, and thus speed up our journey down the highroad to nationalized economy in a socialist state? Or, much more wisely, put our shoulders to the wheel together, catholic employers and catholic employees, and build 
the christian economic democracy demanded by the papal teachings ?

"Today", writes Thomas Lhoest, "there are only two possible solutions: to accept the progressive transfer of responsibilities to the revolutionary trade union masses, who will necessarily create a group of hard and implacable rulers; or to develop the progressive and orderly transfer of personal responsibility to those who share in the production, at the same time giving them their share of the risks to run."

"This second solution", declared Doctor Vittorio Vaccari at the last congress of the API (Association professionnelle des industriels), "is without doubt in the spirit of the principles of christian social doctrine and corresponds to the directives given by the Holy Father to business leaders."

An article published recently in the American review Fortune shows well how, in a materialistic country like the United States, people can face the problem of business leadership realistically and arrive at an equally realistic solution. The author, Neil Chamberlain of the Labor and Management Center of Yale University, gives the answer to the question "What is Management's Right to Manage ?"

In 1851, says Mr. Chamberlain, the New York Journal of Commerce "editorialized that it would not yield 'the control of our business to the dictation of a self-constituted power outside of the office' in the matters of hours and apprenticeship. Today both of these subjects are commonly to be found in collective agreements. In 1945 Inland Steel and other companies fought the union's demand for a voice in a company pension plan. Today welfare programs, including pensions, have become rather widely accepted as a bargaining matter...

“... The trouble with property ownership as a conferer of authority is that it gives command only over things... But when business enterprise assumes a corporate form and requires the cooperation of large numbers of people performing specialized functions, control over things ceases to be sufficient... [and] people can be managed and directed only with their own consent... There is no legal compulsion upon the workers to cooperate... The definition of the terms [of cooperation] is left directly to the parties involved, and there is nothing in the law to stop the union from demanding as the price of the cooperation of its members a voice in some matter previously independently determined by management. Since property rights do not give command over others, management may find it essential to share its autho- rity as a means of including cooperation, in order to maintain the value of a going business...

"In such an analysis unions would have to be viewed not as something falling outside of the structure and processes of management but actually included within its terms". ${ }^{2}$

Let us recugnize that the workman, in his own sphere of work, is much more competent than the employer. Time and practice have given him this superiority. This competence, however, will not grow properly if management is content to use it only by commanding it. But if management asks for the worker's opinions, for suggestions about his work plan, a metamorphosis takes place. From being a mere $\operatorname{cog}$ in the production machine, the workman advances to becoming a thinking member who contributes, as only a man can, to the life and growth of the business. Managers only weaken their authority when they try to go into too great detail in managing, thus letting the workman see their lack of technical knowledge about his job. Feeling himself superior on these occasions, the workman loses confidence and develops a spirit of criticism.

Also, after having heard the opinions of the workers and collected their suggestions, a second step must be taken: teach the workman his role in the forward march of business. "Men", writes Jean Lannoye, "should be subjected to authority as little as possible, but they should very well accept it by a free act following upon their discovery of its necessity, foundations, limits, and disinterested preoccupations." ${ }^{3}$ This is the way, too, by which management can give proof of its intelligence and humanity.

Finally - and here is one brave suggestion toward realizing economic democracy in business - it would be good as a third steps, to ask an opinion from a committee of representatives of each level in the firm, concerning the appointment of the leader of their level. This opinion would not be binding on management.

These reforms certainly require a discernible evolution in minds and consciences. They also imply a certain risk. But we believe this risk is less than the risk of not trying them. To carry them out, both management and workers must renounce their spirit of conflict and recognize the true function of a business firm, which is "to integrate each man into a living community where he will occupy the place naturally belonging to him according to his disposition and merits".

(2) Chamberlain, Neil, "What is management's Right to Manage?", Fortune, July 1949, pp. 68-69-70.

(3) Lannoye, Jean, "L'autorité dans l'entreprise", Bulletin social des industriels, January 1949. 